Golić Darko*

Marković Svetlana ${ }^{* *}$
UDK: 378.1/.112

Review article

DOI: $10.5937 / \mathrm{ptp} 2101025 \mathrm{G}$

Received: February7th 2021

Approved on: February 21st 2021

Pages: $25-41$

\title{
LEGAL NATURE OF HIGHER EDUCATION INSTITUTIONS BYLAWS AND THEIR PLACE IN THE HIERARCHY OF LAW
}

\begin{abstract}
The goals of higher education are achieved through the activities of higher education institutions, which are, in accordance with their guaranteed autonomy, performed on a basis of their bylaws and general policies. The law determines which subjects have a public authority, which subjects are competent to adopt the relevant acts as well as the general range of issues regulated by these acts. The Constitution of Republic of Serbia guarantees that everyone has the right to higher education and, in that regard, the Law on Higher Education of Republic of Serbia regulates the system of higher education, conditions, and methods of performing higher education activities including the basics of its financing and other issues. Management bodies and professional bodies of higher education institutions are specialized in adopting one type of legal acts. In this way, it is enabled these acts, according to their nature or subject matter, to be adopted appropriately. Therefore, higher education institutions, pursuant to the Law on Higher Education, regulate the area of their activities by adopting statutes, regulations, rules of procedure, and other bylaws. The aim of this paper is to point out the legal nature of higher education institutions bylaws as well as their place in the hierarchy of the legal system, and, thus, in the higher education system of Republic of Serbia.
\end{abstract}

Keywords: Higher Education, Higher Education Institution, Bylaws, the Law on Higher Education

\footnotetext{
* LLD., The Faculty of Law for Commerce and Judiciary in Novi Sad, The University of Business Academy in Novi Sad, Serbia, e-mail: darko@pravni-fakultet.info

** LLB., General Secretary, The University of Business Academy in Novi Sad, Serbia, e-mail: smarkovicw@gmail.com
} 


\section{Introduction}

The area of higher education, as a part of the international, European, educational and scientific, as well as artistic space, includes academic and vocational education. In that sense, the activity of higher education is based on the rights aimed at determining study programs, study rules and conditions of student enrollment, the right to regulate the internal organization, adoption of statutes and other bylaws important for the activity of higher education institutions, the right to elect management and other bodies, as well as the right to issue public documents, dispose of funds, use of property, but also the right to decide on the acceptance of projects on international cooperation, in accordance with the Law on Higher Education (Law on Higher Education, 2017, art. 6).

The Constitution of the Republic of Serbia guarantees the autonomy of universities, higher education institutions, and scientific institutions. Autonomy (self-legislation) theoretically necessarily implies the right to a relatively independent regulation of certain issues that are important for preserving the institutional individuality, due to which this autonomy was established (Kutlešić \& Golić, 2017, p. 213). According to the constitutional guarantee, the mentioned institutions should have the possibility determined by law to independently decide on their organization and work. Their independence is not complete, because the right to self-regulation is exercised in accordance with the law, which, depending on the assessment of the legislator, leaves a narrower or broader framework of that freedom (Constitution of the Republic of Serbia, 2006, art. 72). The degree of independence is determined by the need to establish a single system, but also by the need to express the specifics that arise from this activity, in other words, it is the result of balancing between these two principles. Although different possibilities can be envisaged regarding the scope of this right, it should necessarily include the right to determine study programs, study rules and student enrollment conditions, the right to regulate internal organization, enact statutes and other bylaws, and elect management and other bodies, following the framework established by law. Moreover. the constitutional guarantee, having in mind the modern concept of higher education, should include the right to choose teachers and associates, issue public documents, dispose of financial resources, under the law, as well as the right to own and use property and the right to establish various forms of international scientific and educational cooperation and participation in projects arising from cooperation (Law on Higher Education, 2017, art. 6). 
These rights are exercised with respect for human rights and freedoms, whose affirmation they serve, as well transparency towards the public. Autonomy, or "Independent behavior" is the only way in which higher education institutions can function and achieve their goals, but it also requires the obligation of the society to provide instruments that will assess the performance of autonomous institutions and means of exerting an appropriate impact on their improvement (Turajlić, 2006, p. 12).Which is performed by the adoption of certain quality standards, which they must meet in their work, and which are a condition of their existence, that are further controlled by an appropriate independent body. ${ }^{1}$ In the higher education system of Serbia, this role falls to the National Accreditation Body (Law on Higher Education, 2017, art. 14).

An essential component of constitutionally guaranteed autonomy is the right to self-organization. Most importantly, the bodies of a higher education institution, based on the Law, within their competencies, are left with the right to adopt institutional bylaws. The competencies of higher education institutions are primarily prescribed in the Statute, as the highest general policy of the higher education institution. Considering that the activity of higher education is performed by the following higher education institutions: universities, faculties, art academies, within universities, academies of vocational studies, colleges and colleges of applied sciences, there is a difference in enactment, content, and hierarchy of different bylaws of these institutions (Law on Higher Education, 2017, art. 43).

The law created by these bodies of higher education institutions binds all entities to which the conditions provided in their acts apply, and in that regard, the institutions have their autonomous regulations. The beginnings of the understanding of autonomous law, in general, stem from the doctrine of legal pluralism, with the initial idea that in addition to state law, there is natural law, which is not related to the state and as such, stands above the state law.

\section{Bylaws and General Policies}

A legal act, as a set of several legal norms, is expressed and shaped in an appropriate form, and in that sense, legal norms are adopted in groups, in an organized manner, and in the prescribed form. Legal rules of conduct are the result of a set of different actions, psychological as well as material, which are regulated in a formalized procedure, whereby this collection of rules,

\footnotetext{
${ }^{1}$ The constitutional basis for the existence and role of such bodies is the provision on special bodies through which the regulatory function is performed referred to in Article 137, Para. 3.
} 
regulated and shaped, is called a legal act (Kutlešić \& Golić, 2017, p. 67). The characteristic of the legal system, and thus of the legal order, is reflected in the fact that it regulates its creation and thus ensures that all acts and norms that make it up are mutually consistent, acting harmoniously and fulfilling their social function (Mitrović, 2006, p. 163).

The legal order itself regulates the adoption of legal acts, where higher acts regulate not only the procedure of adoption of lower acts, but also their content, and in this regard, both important elements of each legal act are regulated - its form and content (Mitrović, 2006, p. 163). The content of a legal act consists of a norm or part of a norm that is created by an act, whereby the goal of passing an act is aimed at expressing its content, which represents the projected legal relations. However, each instrument must have its own form, a form that consists of two essential elements, the issuer of the act and the necessary procedure needed for the act to be adopted (Lukić, 1995, pp. 112-113). The form of the act is related to its content and each act must be adopted in the form that corresponds to its content.

The procedure for the adoption of legal acts is explicitly and restrictively determined, which ensures uniformity of action while minimizing the potential for different legal interpretations (Pavlović \& Počuča, 2015, p. 59). Given that acts can be divided according to numerous criteria, the basic division is into general and individual legal acts. Although both acts contain norms, special significance is reflected in the general acts, because as such, they represent sources for individual acts, which, as a rule, are adopted in accordance with the general acts. As such, the general norm refers to an indefinite number of cases, and all subjects who meet the conditions provided for in the general norm are obliged to act according to it.On the other hand, an individual norm, which refers only to a certain individual, does not apply to any other subject (Lukić, 1995, p. 114).

The structure of general legal acts includes parts of one legal act, in terms of content, as well as the division of the matter, which is covered by the legal act, in certain parts of the legal act (Pajvančić, 1995, p. 28). Structuring the legal act is particularly important because, in addition to avoiding legal conflict, vagueness, it ensures transparency, coherence, and easier application of a particular act.

Bylaws adopted by the higher education institutions fulfill the previously determined properties of legal acts. Legal acts adopted by the state, primarily laws, as the most important source of law, determine the appropriate formal aspects of these acts - primarily who can issue them, but also the framework for the future content of these acts, which aims to ensure the coherence of 
the system, through prescribed principles of law, higher education goals, determination of the range of issues that fall under autonomous regulation, etc. The law only determines which subjects have normative powers, which subjects are competent to adopt the relevant acts, whereas the management bodies, governing bodies, and professional bodies of higher education institutions specialize in passing certain types of acts, which enables these acts to be adopted in the best possible way, according to their need and nature. Therefore, higher education institutions, based on the Law on Higher Education, regulate their area of activity by adopting statutes, regulations, and other general acts and bylaws.

\section{Legal Status of Higher Education Institutions}

The basic question regarding the legal position of higher education institutions is whether they can, to what extent and with what degree of independence, adopt their own bylaws, create the so-called autonomous law, which would regulate the "internal life" of the institution (Nenadić, 2005, p. 97). To answer this question, it is necessary to point out that according to the Law on Higher Education, all decisions in the field of management, as well as governance of a higher education institution, which includes the adoption of the bylaws of the institution, like the statutes, regulations and other general acts, are adopted independently by the bodies of the institution, and their adoption does not require the consent of other entities. In this regard, the law created by the higher education institution, precisely its bodies, is binding to all entities that meet the conditions provided for in the acts of the institution and are obliged to act in accordance with them.As such, institutions have their own autonomous regulations, have a founding act, and can adopt their own bylaws.

The Constitution of the Republic of Serbia guarantees the autonomy of higher education institutions and as such, they independently decide on their organization and activity, followingthe law (Constitution of the Republic of Serbia, 2006, art. 72). Bearing in mind that this right is recognized for the sake of preserving the specifics arising from the nature of the educational and scientific activities in which they are engaged, it is clear that it is a functional autonomy, as a special form of decentralization, which includes part of the legislature and part of administrative power (Marković, 2015, pp. 401-404). The goals of higher education, which are prescribed by law, and which are aimed at the transfer of scientific, artistic, and professional knowledge, as well as providing equal conditions for acquiring higher education and lifelong learning, through a significant increase in the population with higher 
education, are achieved through activities of the higher education institutions, which they perform based on general acts, both of a state level, and to a significant extent, their own autonomous regulations (Law on Higher Education, 2017, art. 3).

When it comes to autonomous law, as a theoretical concept, it is necessary to point out that it is connected with the modern understanding of legal pluralism, which, unlike the medieval teachings, is a reflection of legal particularism (territorial, personal, functional quasi-autonomy), in its modern meaning, reflects the complexity and dynamics of social relations, with a multitude of subjects of organized social life. In essence, the law is a system that develops in reality, which implies a multitude of factors that shape dynamic social relations, whose legal reflection is created by the interaction of a large number of subjects. This fact determines the situation in which the state is not the only organization that has the right to create its own law, as a system of rules with organized sanctions, but the normative system is a possibility for every social group and community (Vukadinović, 2011, pp. 165-171), and therefore, this right is given to institutions that perform higher education.

In this regard, autonomous law has two main meanings, narrower and broader, wherein the narrower sense the name autonomous law is used for social norms that have all the properties of law, including state sanction, while in another, broader sense, autonomous is viewed as the law that includes all those social norms that are not sanctioned by the state, at least not directly, but which contain important features of legality, including general and social goals, dispute resolution and organized sanctions, which are available to both state and autonomous law creators (Mitrović, 2007, p. 26). Also, the state sanction is present in certain situations, but not as an immediate one, but as a subsidiary, alternative or supplementary one.However, the existence of autonomous law, different from ordinary social rules and their orders, is based on an appropriate connection with the state, which is not exclusively related to the application of state sanctions, as an only option. The existence of the autonomy of higher education institutions by no means implies the absence of an appropriate, important and sufficient role of the state in the field of higher education. The role of the state can be observed in a much wider range of control of legality and regulation of the legal system, it encompasses a wide range of competencies, from financing, management, development, monitoring, supervision and control, care of public services, etc., resulting in a complex, multifunctional connection with autonomous bylaws, without which the existence of the system would be endangered or non-functioning. 
In addition to the fact that the state regulates the system of higher education through the Law, it performs numerous administrative tasks in this area through the Ministry, as a state administration body. Also, ensuring the development and improvement of the quality of higher education is achieved through the work of the National Council for Higher Education, as a special professional body, which is responsible for setting standards for self-evaluation and quality assessment of higher education institutions, external quality control of higher education institutions, initial accreditation, accreditation of higher education institutions and accreditation of study programs (Law on Higher Education, 2017, art. 12). The Ministry of Education, Science, and Technological Development supervises the legality of the work of these institutions, in accordance with the Law on Public Administration (Law on Public Administration, 2005, art. 57, para. 1). Having in mind this diversification of tasks within the competencies of state bodies, legislative, executive, and sui generis, it is clear that the autonomy of universities and other institutions of higher education has its own framework, but also a certain space for expressing its uniqueness, among other ways, through legislative activity.

\section{Higher Education Services}

The services of higher education are of special importance for each country, and today it is defined as a part of a single international space. This uniqueness is ensured by the applicable principles and values on which this activity is based.Although some level of standardization, harmonization, or unification is necessarily implied in providing a single educational space on a wider, supranational level, without a doubt, the autonomy of higher education institutions is part of the list of its unique values because it implies the existence, expression, and respect of special and specific interests such as freedom of scientific thought and activity. This specificity has its formal reflection, contained in the autonomous normative regulation. Higher education, which includes academic and applied education (Law on Higher Education, 2017, art. 2), is proclaimed by the Constitution of the Republic of Serbia as one of the basic human rights, according to which all citizens have the right to access higher education, under equal conditions, whereby the establishment of higher education institutions is regulated by law (Constitution of the Republic of Serbia, 2006, art. 71).

Education, as an important factor in the development of society and humans, is a complex activity, and as such must be viewed in a complex way.The education system, and thus higher education, is an issue of special 
importance for the successful development of society and is inseparable from cultural, economic, and political development, because, in addition to acquiring knowledge, it provides an increase in the social value of highly educated population, with its integral component, scientific research (Marković, 2018, pp. 1-3).

The Law on Higher Education of the Republic of Serbia, following the constitutional guarantee of human rights and autonomy of universities, regulates the system of higher education, as well as the conditions and manner of performing higher education activities, basics of financing higher education, and other issues relevant to this activity (Law on Higher Education, 2017, art. 1). The legislation provides the legal framework for the system of higher education. In this regard, the activities of higher education institutions include the organization, as well as the implementation of the study process and the implementation of teaching (Stefanović, Parezanović \& Kaplarević, 2000, p. 44). In addition to performing public service, and administrative powers in the narrower sense (administrative acts, records, public documents) (Milkov, 2009, pp. 16-17), their independence includes a normative component, which is not only in the function of closer regulation of certain issues but also includes the right to independently regulate certain issues within the established legal framework.

Higher education institutions perform the activity of higher education based on public authority entrusted to them by law. Moreover, in addition to state administration bodies, as the basic holders of the administrative function, non-state entities, companies, institutions, and other organizations may also perform administrative activities, when these competencies are entrusted to them by law.Institutions, companies, and other organizations are located outside the state apparatus, they independently perform certain professional, economic, and similar activities, and thus educational activities (Milkov, 2016 , p. 96). The law also regulates the system of relations between state bodies and holders of public competencies, primarily the subject and scope of supervision and supervisory competencies.

Unhindered performance of the basic activity of these non-state entities also enables a certain authority in termsof representation and imposing will on individuals and other organizations. Considering that the possibility of exercising power is not implied for non-state entities, they need explicit legal authorization to do so, they must be entrusted by law with public or administrative powers, which in turn implies the possibility to act authoritatively. They can be entrusted only with certain, precisely determined public competencies, which may include the adoption of administrative acts, by which they decide 
on the rights, obligations, and legal interests of specific subjects in administrative matters. Therefore, the basis for exercising these powers can only be the law (Milkov, 2016. pp. 96-97).

In this regard, the provision of a single international space, and the optimal functioning of this public service, requires appropriate principles, according to which the basic activity of higher education is based on principles of academic freedom, autonomy, unity of teaching, research, and artistic work and innovative activities, professional work, academic integrity, harmonization with the European system of higher education and improving the academic mobility of teaching and non-teaching staff and students, ensuring the quality and efficiency of the studies, connection with pre-university education and protection of intellectual property, in knowledge transfer processes (Law on Higher Education'2017, art. 4).

\section{The Hierarchy of Higher Education Institution's Bylaws}

The legal system contains the principle of hierarchy of legal acts and legal norms. All legal acts, and thus legal norms, which are contained within them, take their place in the legal order, according to the principle of hierarchy, they hold a place on a scale of higher and lower acts so that at the top are the highest, and on the base, the lower acts, under which there are only material acts, actions of execution of legal acts (Lukić, 1995, p. 156).

When it comes to the hierarchy of legal norms, and thus the hierarchy of acts, in which those norms are contained, the hierarchy of legal acts depends on their legal power. Between a vast number of legal acts, there must be a certain mutual relationship, which constitutes a complex legal order. For that reason, the question of establishing a hierarchy of norms and acts arises as a necessity, which essentially leads to the establishment of cooperation between the issuers of acts (Simović, 1998, p. 150). Besides, it is necessary to have institutional mechanisms to enforce the harmonization of legal acts according to their place in the hierarchy.

Therefore, the legal power of a legal act can be defined as a measure of influence, which one act exerts on other acts, and as a measure of mutual influence. The legal power of an act depends on its form, not on its content, although it is quite obvious that the form is dictated by the content (Vasić \& Čavoški, 1996, p. 147). The hierarchy of legal acts is a reflection of the hierarchy of their issuers, and thus the formal properties of an act. In that sense, the legal hierarchy of acts is not permanent and unchangeable (Lukić, 1995, p. 
157). This hierarchy is crucial for the proper functioning of the law, and thus the proper performance of higher education activities, within a single system.

Each legal act has a certain legal force, which means that each legal act has a certain place in the hierarchy of legal acts and thus has a certain degree of influence on other legal acts. In that sense, the higher the place in the hierarchy, the greater the legal power and vice versa. Therefore, legal power is a measure of the influence of the effect that one legal act has on the other (Lukić, 1995, p. 157). This power has its formal and material reflection.

The normal functioning of the legal system, and thus the realization of the interests of the state, requires that all its parts be harmoniously interconnected.In addition to horizontal harmony, it is necessary for the legal order of the country to be harmonized vertically, which means that all legal acts should be harmonized in such a way that they do not contradict each other, those with less legal force must not contradict acts of stronger legal force, all the way to the Constitution, as the highest legal act of the state (Carić, 2016, p. 15).

In this regard, it is necessary that the higher education institutions, as holders of normative powers, in regulating their relations know how to distinguish sources related to higher education and to knowingly "arrange" them according to their legal force on a certain scale, in order to properly applied the appropriate regulation to a specific case, and thus ensure the respect for legality and legal certainty in the performance of their activities (Carić, 2016, p. 15).

The hierarchy of legal acts related to higher education in the Republic of Serbia is defined and begins with the Constitution of the Republic of Serbia, the highest hierarchical act, which contains basic principles related to higher education, distribution of competencies in this area, hierarchy, and ensuring the uniformity of the legal order (Constitution of the Republic of Serbia, 2006, art. 194-195) and delegation of state competencies, followed by ratified international agreements, then the laws, with the most important legal act in this field being the Law on Higher Education. Then the bylaws are applied, adopted according to the law. The Constitution establishes the competence of the Constitutional Court to exercise broad normative control, including the harmonization of general acts of higher education institutions with the Constitution and the law (Kutlešić \& Golić, 2017, p. 253).

Although formally they are among the bylaws in the case when they are adopted based on delegated legal competencies, depending on the scope of legal competencies to independently regulate certain issues, certain provisions of general acts of higher education institutions can be classified into legislation in material terms, which falls under the definition of the autonomy 
of these subjects. When it comes to regulating the internal organization and determining the legal status of higher education institutions, which in this regard have certain powers in legal relations, higher education institutions in their founding and other bylaws determine or more closely regulate the basic tasks and goals, which are in line with the goals of higher education which are determined by law.

The Statute is the basic bylaw of a higher education institution, which regulates the manner of work, organization of the institution, management, and leadership, but also other issues that are important for the performance of activities and work of the higher education institution, in accordance with the Law (Law on Higher Education, 2017, art. 56). It is also important to mention that the regulations on public services are applied to the establishment and operation of higher education institutions unless otherwise regulated by the Law (Law on Higher Education, 2017, art. 43, para. 9). After the Statute, the rules of the institution follow, and then the rules of procedure of the collegial bodies of these institutions. Unlike other lower acts, certain provisions of the Statute, primarily in independent institutions, may have the character of legislation in the material sense, because they are not only or strictly implementing the law, but also have a certain creative power, the possibility of original normative creation. Among other, universities, academies of applied sciences, colleges, and colleges of applied sciences belong to independent higher education institutions. On the other hand, faculties and art academies are higher education institutions, precisely, higher education units within the university, which in legal relations act under the name of the university, which they are part of in addition to their name, following the university's Statute, which means that the university gives consent to the Statute of the higher education unit, which is part of the university. In that sense, the faculty or the art academy, but also other higher education units with the status of a legal entity, regulate their internal organization and management in their Statute in accordance with the Statute of the university (Law on Higher Education, 2017, art. 57, para. 12).

The bodies of higher education institutions are regulated by the Statute of the institution, under the law and the founding act.By appointing certain competencies of some of the bodies, the law restricts the right to self-organization, as in the case of prescribing the competencies of the management body, the University Council that adopts the Statute, at the proposal of the expert body.

Faculties are competent to adopt their general acts, usually in the form of internal rules. They must be in accordance with the bylaws of the University. They are adopted in many areas, such as: determining the manner and procedure of conducting self-evaluation, defining the manner and procedure for 
determining the disciplinary responsibility of students, the manner of election and number of members of the student parliament, managing revenue, criteria for determining tuition fees, titles and employment of teaching and nonteaching staff, more detailed conditions and ways of executing the distance learning program, as well as the rules of studies.

In certain cases, provided by law, the faculty independently regulates certain issues within its competence. In this regard, the Law stipulates that the faculty may organize examinations and perform certain parts of studies, as well as organize the preparation and defense of final, master's and specialist work and doctoral dissertation, in the language of a national minority and a foreign language, in accordance with the Statute (Law on Higher Education, 2017, art. 95, para. 2).These issues fall within the scope of an independent normative scope. The bylaws also regulate the number of students who enroll in a certain study program, which cannot be higher than the number determined in the work permit, in accordance with the Statute of the faculty (Law on Higher Education, 2017,art. 105, para. 7), as well as the number and date of exams and deadlines, etc. (Law on Higher Education, 2017, art. 105, para. 7).

Certain regulations adopted by universities, as independent higher education institutions, directly create obligations for the faculties and art academies that are part of the university. They are adopted depending on how competencies are distributed between these institutions.In that sense, the procedure of preparation and conditions for the defense of the dissertation, art project, as well as criteria and conditions for transferring ECTS credits, cancelation of a study program, conditions and manner of enrolling students in accredited study programs, but also scientific research, artistic work, and evaluation of pedagogical work of teachers, are regulated by university regulations.Also, the university bylaws regulate the conditions for tenure, as well as the manner and procedure of employment and acquisition of the title of a professor, the manner of hiring visiting professors, the procedure and conditions for granting the title of professor emeritus, and the conditions and procedure for giving the teaching staff consent to work in other higher education and health institutions.

The competence of the bodies of higher education institutions also includes the adoption of another type of bylaw - the rules of procedure. The Rules of Procedure are a type of bylaw, by which the collegial bodies regulate in more detail their internal organization and work, position, and manner of exercising the rights and duties of their members. These types of bylaws are adopted by the council, senate, and student parliament, at the level 
ofindependent higher education institutions, while faculties adopt the rules of procedure of their professional bodies - councils, academic council, artistic council, and student parliament.Also, in addition to prescribing the procedure for the work of permanent bodies, the rules of procedure may regulate the matter of auxiliary and temporary bodies, commissions, and boards, following the needs of the higher education institution.

The university integrates the functions of faculties and art academies, and other membersof higher education units, by implementing a unified policy, the aim of which is targeted at improving the quality of teaching, improving scientific research and artistic work, and providing support to students in academic and career development. In order to achieve these goals, the university, in addition to the above mentioned, has other competencies, which it implements in the areas of strategic planning, adoption of study programs, quality assurance and control, enrollment policy, and definition of codes of professional ethics and rules of conduct in the institution. Furthermore, the issue of international cooperation and mobility of interest to the university as a whole is regulated by the Statute of the University (Law on Higher Education, 2017, art. 58).

\section{Conclusion}

The legal position of higher education institutions in Serbia implies the possession of normative authorizations, that can be used to create the socalled. autonomous law of the institution, which regulates its "internal life". The Constitution of the Republic of Serbia, as the highest legal act, guarantees the autonomy of higher education institutions that independently decide on their organization and work, in accordance with the law. The Constitution guarantees autonomy, but its framework is determined by law. This framework, depending on the legislator's assessment, can be narrower or broader, with both, the danger that autonomy will be stripped of real content, for the sake of establishing a stronger, unified system, or set too wide to the extent that the existence of the system is called into question.However, this is a political issue, the resolution of which is up to the of the Parliament. Besides, the framework of that freedom is not limitless. It is determined by certain social values and generally accepted principles of policy in the field of higher education, which, although changeable, are not necessarily and completely legally regulated or determined by state bodies. The activity of higher education based on the basic principles of academic freedom, autonomy, as well as academic integrity, is of special importance for each country that aspires to be 
part of a single international, educational, scientific, or artistic space. This is an essential measure of the autonomy of universities and other institutions in the field of higher education.

Under the Law on Higher Education, as the most important legal source in this field, all decisions in the area of operation, as well management of higher education institutions, which includes the adoption of institutions bylaws, like statutes, regulations, and other general acts, are independently adopted by the bodies of the institution, in accordance with the law. The law created by higher education institutions, precisely, its bodies, is binding for all subjects who meet the conditions provided in the acts of the institution. Accordingly, institutions have their own autonomous regulations, have a founding act, and can adopt their own bylaws.

Higher education institutions have, also, freedom in their scientific research and artistic work. It arises from the freedom to choose the way of interpreting the teaching content, it is also realized through the procedure of determining the underlying tasks and goals of the institution, which are in accordance with the goals of higher education established by law. This leads to the conclusion that legislative solutions do not call into question the constitutional guarantee of a university's autonomy.

Although they formally belong to bylaws, depending on the degree of independence in regulating certain issues by law, certain general acts of higher education institutions are not only used for implementing legal norms but to some extent originally regulate a certain (albeit limited) number of issues.For all higher education institutions, the Statute is the highest bylaw. It is an act of organizational character, which regulates the basic issues of the organization and work of the institution. However, the most important issues, which bring to life the legal and statutory solutions, are regulated by rules and regulations adopted by University bodies. However, there are certain limitations in their adoption or content, which higher education institutions must take into account, depending on their legal status, which is determined by the fact whether they have the status of an independent higher education institution or represent higher education institutions or higher education units within a University. 


\section{Golić Darko}

Doktor pravnih nauka, Pravni fakultet za privredu i pravosuđe u Novom Sadu, Univerzitet

Privredna akademija u Novom Sadu, Srbija

\section{Marković Svetlana}

Diplomirani pravnik, generalni sekretar, Univerzitet Privredna akademija u Novom Sadu, Srbija

\section{PRAVNA PRIRODA OPŠTIH AKATA VISOKOŠKOLSKIH USTANOVA I NJIHOVO MESTO U HIJERARHIJI PRAVA}

REZIME: Ciljevi visokog obrazovanja ostvaruju se kroz delatnost visokoškolskih ustanova, koju, u skladu sa garantovanom autonomijom, vrše na osnovu svojih opštih akata. Zakonom se određuje koji subjekti imaju javno ovlašćenje, odnosno koji subjekti su nadležni da donose odnosne akte, kao i opšti krug pitanja koja se tim aktima uređuju. Ustav Republike Srbije propisuje da svako ima pravo na visoko obrazovanje i u tom pogledu, Zakon o visokom obrazovanju Republike Srbije uređuje sistem visokog obrazovanja, uslove i način obavljanja delatnosti visokog obrazovanja, kao i osnove njegovog finansiranja, te druga pitanja od značaja za obavljanje ove delatnosti. Organi poslovođenja, organi upravljanja i stručni organi visokoškolskih ustanova, specijalizirani su za donošenje jedne vrste akata, čime je omogućeno da se ti akti, shodno njihovoj prirodi ili predmetu donose na odgovarajući način. Samim tim, visokoškolske ustanove, na osnovu Zakona o visokom obrazovanju, oblast svog delovanja regulišu donošenjem statuta, pravilnika, poslovnika i drugih opštih akata. Cilj rada je da se ukaže na pravnu prirodu opštih akata visokoškolskih ustanova, kao i njihovo mesto u hijerarhiji pravnog, a time i visokoobrazovnog sistema Republike Srbije.

Ključne reči: visoko obrazovanje, visokoškolska ustanova, opšti akt, Zakon o visokom obrazovanju. 


\section{References}

1. Carić, S., Vitez, M., Dukić Mijatović, M. \& Veselinović, J. (2016). Privredno pravo [Commercial Law]. Novi Sad: Fakultet za ekonomiju i inženjerski menadžment, Univerzitet Privredna akademija u Novom Sadu

2. Kutlešić, V., \& Golić, D. (2017). Uvod u pravo [Introduction to Law]. Novi Sad: Pravni fakultet za privredu i pravosuđe u Novom Sadu

3. Kutlešić, V., \& Golić, D. (2017). Ustavno pravo [Constitutional Law]. Novi Sad: Pravni fakultet za privredu i pravosuđe u NovomSadu

4. Lukić, R. (1995). Teorija države i prava II. Teorija prava [Theory of State and Law II. Theory of Law]. Beograd: Beogradski izdavačko - grafički zavod; Zavod za udžbenike i nastavna sredstva

5. Marković, R. (2015). Ustavno pravo [Constitutional Law]. Beograd: Pravni fakultet

6. Marković, S. (2018). Uticaj reformi visokog obrazovanja na položaj univerziteta u Republici Srbiji [The impact of higher education reforms on the position of universities in the Republic of Serbia] In: XXIV Skup Trendovi razvoja: digitalizacija visokog obrazovanja - Trend : zborn$i k$ radova [Proceedings from the XXIV Conference Trends of development: Digitalization of Higher Education] ( pp. 1-3). Downloaded 2020, June 25 from:http://www.trend.uns.ac.rs/stskup/trend_2018/radovi/T1-2/ T1.2-7.pdf

7. Milkov, D. (2009). Upravno pravo - Uvodna i organizaciona pitanja [Administrative Law - Introductory and Organizational Questions]. Novi Sad: Centar za izdavačku delatnost, Pravni fakultet, Univerzitet u Novom Sadu

8. Milkov, D. (2016). Upravno pravo I - uvodna i organizaciona pitanja [Administrative Law I - Introductory and Organizational Questions]. Novi Sad: Centar za izdavačku delatnost, Pravni fakultet, Univerzitet u Novom Sadu

9. Mitrović, D. (2006). Osnovi prava. [Basics of Law]. Beograd: Univerzitet Singidunum, Fakultet za turistički i hotelijerski menadžment

10. Mitrović, D. (2007). Autonomno pravo [Autonomous Law]. Beograd: Pravni fakultet, Univerziteta u Beogradu

11. Nenadić, B. (2005). Pravni položaj ogranka privrednog društva. [Legal Status of a Company Branch], Pravo i privreda, 5(8), pp. 83-99

12. Pavlović, Z., \& Počuča, M. (2015). Izrada pravnih akata [Drafting Legal Acts]. Novi Sad: Univerzitet Privredna akademija u Novom Sadu 
13. Pajvančić, M. (1995). Pravno normiranje [Legal Regulation]. Novi Sad: Centar za izdavačku delatnost -Pravni fakultet, Univerzitet u Novom Sadu; Advokatska komora Vojvodine

14. Simović, M. (1998). O hijerarhiji pravnih normi [On the Hierarchy of Legal Norms]. Zbornik Pravnog fakulteta u Nišu, 38(39), pp. 148-156

15. Stefanović, D., Parezanović, D., \& Kaplarević,A. (2000). Poslovne i nastavne aktivnosti visokoškolskih ustanova u Internet okruženju. [Business and teaching activities of higher education institutions in the Internet environment]. Management - časopis za teoriju i praksu menadžmenta,5 (17-18), pp. 44-51

16. Turlajić, S. (2006). Univerzitet i država - misija, autonomija i odgovornost [Universities and State - Mission, Autonomy and Responsibility] In: XII skup Trendovi razvoja:Bolonjski proces i primena novog zakona : zbornik radova, [Proceedings from the XII Conference Trends of development: Bologna Process and apliccation of the new Law] (pp. 9-13) Downloaded 2020, June 15 from: http://www.trend.uns.ac.rs/stskup/ zbornik/radovi/uvodni/u1.pdf.

17. Ustav Republike Srbije [Constitution of the Republic of Serbia]. Sl glasnik $R S$, no. 98/06

18. Vasić, R., \& Čavoški, K. (1996). Uvod u pravo II [Introduction to Law II]. Beograd: Draganić

19. Vukadinović, G.(2011). O pojmu autonomnog prava. [On the Notion of Autonomous Law]. Zbornik radova Pravnog fakulteta, Novi Sad, 45(3), pp. 163-172

20. Zakon o visokom obrazovanju [Law on Higher Education]. Službeni glasnik $R S$, no. 88/17, 27/18 - other laws, 73/18, 27/18 -other laws, 67/19 and $6 / 20-$ other laws

21. Zakon o državnoj upravi [Law on Public Administration]. Službeni glasnik $R S$, no. 79/05, 101/07, 95/10, 99/14, 47/18 and 30/18 -other laws 